\title{
Comparison between Patients with Persistent Pulmonary Hypertension of Neonates Concomitant with Parenchy- mal Lung Disease and Idiopathic Persistent Pulmonary Hypertension of Neonates
}

In Kyung Ryu, Chih Lung Tang, Shou Yu Chu, Gyu Hong Shim, and Myoung Jae Chey

Department of Pediatrics, Inje University Sanggye Paik Hospital, Seoul, Korea

\section{ABSTRACT}

Purpose: We aimed to compare the clinical characteristics between neonates with persistent pulmonary hypertension of neonates (PPHN) with parenchymal lung disease (PLD) and those with idiopathic PPHN.

Methods: We reviewed the medical records of 67 neonates with gestational ages not lesser than $34^{+0}$ weeks who were born at Inje University Sanggye Paik Hospital between June 1, 2005 and December 31, 2016. We excluded 10 neonates who presented with congenital anomalies $(\mathrm{n}=3)$, dextrocardia $(\mathrm{n}=1)$, triple $\mathrm{X}$ syndrome $(\mathrm{n}=1)$, death before treatment $(\mathrm{n}=1)$, neonatal asphyxia $(\mathrm{n}=2)$, and congenital diaphragmatic hernia $(\mathrm{n}=2)$. Neonates were categorized into 2 groups-PPHN with PLD (PLD group, those diagnosed with PLD such as respiratory distress syndrome or meconium aspiration syndrome, $\mathrm{n}=36$ ) and idiopathic PPHN (idiopathic group, $\mathrm{n}=21$ ). We compared the clinical characteristics, treatment, and laboratory findings between the groups.

Results: The PLD group neonates showed a greater requirement for positive pressure ventilation in the delivery room, higher frequency of meconium staining of amniotic fluid, and greater need for surfactant application than those belonging to the idiopathic group. In contrast, epinephrine use was more common in the idiopathic PPHN group than in the PLD group. The 1-minute Apgar score and $\mathrm{pH}$ observed on initial capillary blood gas analysis were lower in the PLD than in the idiopathic group. Severity scores were higher in the idiopathic than in the PLD group 4-7 days after birth. Conclusion: In our study, an overall simplified severity score in the first week after birth was higher in the idiopathic than in the PLD group. These results were particularly statistically significant over postnatal days $4-7$.

Key Words: Persistent pulmonary hypertension of the newborn, Neonate, Parenchymal lung disease
Received: 12 August 2017

Revised: 27 September 2017

Accepted: 13 October 2017

Correspondence to: Gyu Hong Shim

Department of Pediatrics, Inje University Sanggye Paik Hospital, Dongil-ro 1342, Nowon-gu, Seoul 01757, Korea

Tel: +82-2-950-1632

Fax: +82-2-950-1246

E-mail:peddoc@paik.ac.kr

Copyright(c)

By Korean Society of Neonatology.

All right reserved.

This is an Open-Access article distributed under the terms of the Creative Commons Attribution Non-Commercial License (http://creativecommons.org/licenses/ by-nc/4.0), which permits unrestricted non-commercial use, distribution, and reproduction in any medium, provided the original work is properly cited. 
서론

신생아 지속성 폐동맥 고혈압(persistent pulmonary hypertension of the newborn, PPHN)은 태아 순환이 신생아기 순환으로 전환하 지 못하고 폐혈관 저항이 전신 혈관 저항보다 지속적으로 높은 상태 가 지속되어 출생 직후 난원공이나 아직 닫히지 않은 동맥관을 통해 우좌 단락의 혈류가 발생하여 이에 의한 저산소성 호흡부전을 초래 하는 질환을 말한다 ${ }^{1,2)}$. 유병률은 후기 미숙아와 만삭아에서 1,000 명 당 2 명 정도이며, 현재까지도 $11 \%$ 에 이르는 높은 사망률을 보이는 것으로 알려져 있다 ${ }^{3)}$. PPHN은 발생기전에 따라 폐혈관의 개수는 정 상이나 폐실질 질환(parenchymal lung disease, PLD)에 의한 과도한 폐혈관 수축이 유발되는 경우와 폐실질은 정상이나 폐혈관의 평활 근이 과하게 두꺼워 지거나 세엽내 동맥의 수준의 폐혈관의 재형성 이상인 경우(idiopathic PPHN), 폐혈관의 개수 감소와 동반된 폐형 성 부전에 의해 유발되는 경우로 나눌 수 있으며, 일반적으로 폐실질 질환에 의한 경우가 가장 예후가 좋다고 알려져 있다 ${ }^{4,5)}$. 그러나 현 재까지의 국내 연구 중 신생아 지속성 폐동맥 고혈압의 원인에 따른 임상적 차이나 예후 등에 관한 비교 연구는 많지 않은 실정이다.

이에 저자들은 본원에 입원한 PPHN 환자들의 의무기록을 후향 적으로 분석하여 폐실질 질환이 동반된 PPHN group과 idiopathic PPHN group의 두 군간에 임상적 인자, 검사결과, 치료 및 예후에 차 이가 있는 지를 알아보고자 본 연구를 시행하게 되었다.

\section{대상 및 방법}

\section{1. 대상}

2005년 1월부터 2016년 12월까지 12년 동안 인제대학교 상계백병

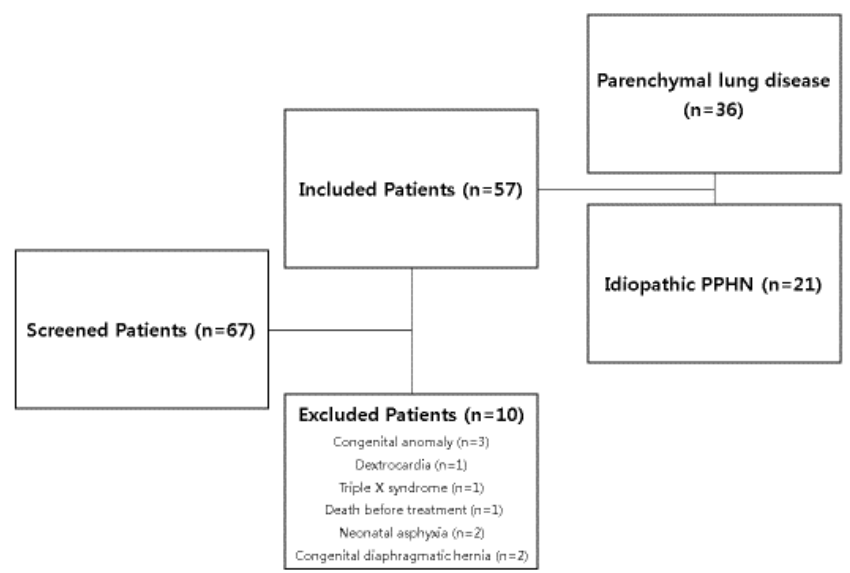

Figure 1. Flow diagram illustrating the selection of the PPHN patients. Abbreviation: PPHN, persistent pulmonary hypertension of the newborn.
원 신생아 중환자실에 입원한 재태연령 34 주 이상의 환자들 중 심장 초음파상에서 삼첨판 역류 $3.5 \mathrm{~m} / \mathrm{sec}$ 이상 혹은 심방수준에서의 우 좌 단락이 확인되어 PPHN으로 확진된 67명의 환자를 대상으로 하 였다(Figure 1). 치료 받기 전에 사망한 환자 1명, 우심증 1명, 염색체 이상(triple X syndrome) 1 명, 선천성 다발성 기형이 있었던 환자 3 명, 선천성 횡격막 탈장 2 명 및 신생아 가사 2 명 등 총 10 명을 제외하 였다. 후향적으로 의무기록을 검토하였으며 PLD group에는 신생아 호흡 곤란 증후군(respiratory distress syndrome, RDS), 태변 흡인 증 후군(meconium aspiration syndrome, MAS)과 악성 일과성 신생아 빠른호흡(malignant transient tachypnea of the newborn, malignant TTN)이 포함되었으며, idiopathic group에서는 idiopathic PPHN이 포함되었다.

\section{2. 방법}

PPHN 환자에 대하여 산전 요인과 신생아적 요인에 대해 조사 하였다. 산전 요인으로는 재태 연령, 산모 나이, 초산 여부, 분만 방 법, 분만 직전 출혈 여부, 조기 양막 파수 여부, 양수 과소증 여부, 임 신성 고혈압, 임신 중 당뇨 여부, 산모 약물력과 병리학적 융모양막 염 여부 등에 대해 조사하였다. 신생아적 요인으로는 출생 당시 임 상적 특성 및 동반 질환, 혈액 검사 소견 및 심장초음파 소견, 시행 된 치료에 대하여 조사하였다. 출생 당시 임상적 특성으로는 재태 연령, 출생 체중, 성별, 본원 출생 여부, 1 분과 5 분 아프가 점수, 부 당중량아 여부, 부당경량아 여부, 분만 직후 태변착색 여부, 분만장 에서 양압환기 여부 및 분만장에서 기관 내 태변 흡인 처치 여부 등 에 대하여 조사하였다. 동반 질환으로는 저산소성 허혈성 뇌증, 경 련, 뇌실 내 출혈, 기흥, 폐출혈, 신생아 패혈증, 저혈당, 고혈당, 저 칼슘혈증, 급성 신부전 및 사망 등에 대해 조사하였다. 혈액 검사는 입원 초기에 시행된 일반 혈액 검사, 생화학 검사와 모세관가스분석 결과를 조사하였으며, 모세관가스분석결과는 Stat Profile ${ }^{\circledR}$ PRIME $^{\mathrm{TM}}$ CCS Analyzer (Nova Biomedical, Waltham, MA, USA)를 사용하였 다. 심장 초음파소견으로는 PPHN 진단까지 소요된 출생 후 시간, 동 맥관 개존 크기, 우좌 단락 여부 및 삼첨판 역류 속도 등에 대해 조사 하였다. 치료의 경우 본원에서는 심초음파에서 좌심실 수축도가 감 소한 경우에 milrinone을 투여하였으며, 산소화 지수(oxygenation index, OI)가 15 이상인 경우에 흡입 일산화 질소를 사용하였으며, 흡입 일산화 질소 치료 후 24시간 이후에도 반응이 없는 경우 ilioprost, sildenafil, bosentan을 사용하였다. 이외에도 입원 기간, 인 공 폐 표면 활성제 사용 여부, 산소 투여 기간, 인공환기기 적용 기 간, 고빈도 환기기 사용 유무, 흡입 일산화 질소 사용 유무, sildenafil, iloprost, bosentan, milrinone 사용 여부, dopamine, epinephrine, vasopressin, hydrocortisone 사용 여부, 진정제 사용 여부(fentanyl 또는 midazolam), 항생제 사용 여부 및 면역 글로불린 투여 여부, 적 혈구, 신선 동결 혈장, 혈소판 수혈 여부 및 입원 이후 7일간의 단순 
화된 중증도 점수(a simplified severity score, SS) 등에 대하여 조사 하였다.

\section{3. 정의}

$\mathrm{PPHN}$ 은 임상적으로 동맥관 전과 후의 산소포화도 차이가 10 $\mathrm{mmHg}$ 이상 차이가 발생하며 소아 심장분과전문의가 시행한 심장 초음파 검사에서 삼첨판 역류 $3.5 \mathrm{~m} / \mathrm{sec}$ 이상 혹은 우심실 최대 수축 기압, 심방수준에서의 우좌 단락의 유무, 수축기말 역설적 심실중격 운동 유무를 평가하여 PPHN으로 진단 내린 경우로 정의하였다 ${ }^{6,7)}$. 신생아 호흡 곤란 증후군의 경우에는 뚜렷한 호흡곤란 증후를 보이 며 흥부방사선 사진상 폐용적의 감소 또는 air-bronchogram 등의 의 심 소견이 있는 경우로 하였다 ${ }^{8)}$. 태변 흡인 증후군의 정의는 분만 당 시 태변 착색 된 양수를 흡인한 경우에서, 출생 2 시간 이내에 산소 공 급이 필요한 호흡곤란이 있었으며, 흉부 방사선상 소견으로 양 폐의 과팽창 및 폐음영의 증가를 보이는 경우로 정의하였달. 악성 일과 성 신생아 빈호흡은 제왕절개로 태어난 신생아에서 PPHN으로 진행 하여, 심각한 호흡기 질환의 이환율과 사망률 보이는 경우로 정의하 였다 ${ }^{10)}$. 조기 양막 파수는 분만 18시간 이전에 양막이 파열된 경우로 정의하였다. 양소 과소증 여부는 양수지수가 $5.0 \mathrm{~cm}$ 이하인 경우로 정의하였으며 ${ }^{11)}$, 임신성 고혈압은 수축기 혈압 $140 \mathrm{mmHg}$, 이완기 혈압이 $90 \mathrm{mmHg}$ 초과인 경우로 정의하였다 ${ }^{12)}$. 임신성 당뇨의 경우 에는 과거력 없는 산모에서 당뇨가 의심되는 산모에서 $50 \mathrm{~g}$ 경구 당 부하 검사를 시행하여 혈당이 $130 \mathrm{mg} / \mathrm{dL}$ 이상인 경우 확진 검사를 시행하였으며, 확진 검사로 $100 \mathrm{~g}$ 경구 당부하 검사를 시행하여 공 복 혈당 $95 \mathrm{mg} / \mathrm{dL}$ 이상, 식후 1시간 혈당 $180 \mathrm{mg} / \mathrm{dL}$ 이상, 2시간 혈 당 $155 \mathrm{mg} / \mathrm{dL}$ 이상 혹은 3 시간 혈당 $140 \mathrm{mg} / \mathrm{dL}$ 이상 중에 2가지 이 상 만족한 경우로 정의하였다 ${ }^{13)}$. 병리학적 융모양막염의 경우 병리 학적 검사에서 중증도 2 이상의 양막 또는 융모 기저막염인 경우나 중증도 1 이상의 funisitis가 있을 때로 정의하였다 ${ }^{14)}$. 출생 체중이 재 태연령에 따른 체중분포의 10 백분위수 미만인 경우를 부당경량아 (small for gestational age, SGA), 90 백분위수 초과인 경우를 부당중 량아(large for gestational age, LGA)로 정의하였다 저산소성 허혈성 뇌증은 Sarnat와 Sarnat에 의한 저산소 허혈 뇌병증의 임상적 단계를 바탕으로 등급화 하였다 ${ }^{15)}$. 뇌파에 이상 소견과 함께 임상적 경련이 동반되어 약물 치료를 시행한 경우를 경련이라고 정의하였으며, 뇌 실 내 출혈은 Volpe의 기준에 따라 grade 2 이상인 경우로 정의하였 다 ${ }^{16)}$. 기흥은 폐에 공기누출이 있는 환자 중에 흥강천자 이상의 치 료가 필요한 경우로 정의하였다. 패혈증은 혈액 배양검사에서 균이 동정된 경우로 하였다 ${ }^{17)}$. 저혈당의 경우 혈중 포도당 수치 $50 \mathrm{mg} / \mathrm{dL}$ 미만으로 치료가 필요한 경우로 정의하였으며 ${ }^{18)}$, 고혈당의 경우 250 $\mathrm{mg} / \mathrm{dL}$ 이상의 고혈당이 지속되어 혈당 조절을 위해 인슐린을 투여 한 경우로 정의하였다 ${ }^{19)}$. 저칼슘혈증은 혈중 칼슘이 $7.0 \mathrm{mg} / \mathrm{dL}$ 이하 이면서 칼슘 투여 치료를 받은 경우로 정의하였다 ${ }^{20)}$. 급성 신부전의
경우에는 초기 혈장 내 크레아티닌 수치가 정상치의 2 배이면서, 도 착 당일 24 시간 동안 소변양이 $1.0 \mathrm{~mL} / \mathrm{kg} / \mathrm{hr}$ 미만인 경우로 정의하 였으며 ${ }^{21)}$ Severity score (SS)는 동맥카테더 유지가 힘든 신생아에서 고안된 점수로 평균 기도압(mean airway pressure, MAP)과 흡입 산 소 분율(fraction of inspired oxygen, $\mathrm{FiO}_{2}$ ) 을 곱해서 얻어지는 점수 로 신생아 산소 치료의 목표가 88-94\%이며 목표 동맥혈 산소 분압 이 40-70 mmHg인 점을 고려하여, SS 3.5점이 OI 5-9점과 비슷한 값을 가진다 ${ }^{22,23)}$.

\section{4. 통계}

통계학적인 분석을 위해 SAS version 4.2 (SAS Institute, Cary, NC, USA)를 사용하였으며, 범주형 변수들은 카이제곱 검정과 피셔 검정 를 사용하고 연속변수들은 Student t-test과 Mann Whitney U-test를 사용하여 분석하였으며, $P$ 값이 0.05 미만인 경우를 통계학적으로 의 미가 있다고 판단하였다.

\section{결과}

총 57명의 PPHN 환자 중 PLD group이 36명, idiopathic group이 21명이었다. PLD group은 세부 원인은 MAS 20명(55.0\%)과 RDS 13 명(36.0\%), malignant TTN 3명(9.0\%)이었다.

\section{1. 산전 요인}

산모나이, 초산부, 분만 방법, 분만 전 출혈 여부, 양막 조기 파수 여부, 양수과소증 여부, 임신성 고혈압 및 임신 중 당뇨 여부, 산모

Table 1. Antepartum variables of the Persistent Pulmonary Hy pertension of Newborn with Parenchymal Lung Diseases and Idiopathic PPHN

\begin{tabular}{lccc}
\hline & $\begin{array}{c}\text { PLD group } \\
(\mathrm{n}=36)\end{array}$ & $\begin{array}{c}\text { Idiopathic group } \\
(\mathrm{n}=21)\end{array}$ & $\begin{array}{c}P \text { - } \\
\text { value }\end{array}$ \\
\hline Maternal age (y) & $32.3 \pm 3.2$ & $31.6 \pm 4.7$ & 0.539 \\
Primiparity & $20(55.6)$ & $10(47.6)$ & 0.563 \\
Emergency delivery & $27(75.0)$ & $13(61.9)$ & 0.297 \\
C-sec delivery & $13(36.1)$ & $7(33.3)$ & 0.832 \\
Antepartum hemorrhage & $1(2.8)$ & $0(0)$ & 1.000 \\
PROM & $5(13.9)$ & $0(0)$ & 0.146 \\
Oligohyramnios & $1(2.8)$ & $0(0)$ & 1.000 \\
PIH & $3(8.3)$ & $1(4.8)$ & 1.000 \\
Maternal diabetes & $2(5.6)$ & $3(14.3)$ & 0.346 \\
Histologic chorioamnionitis & $0(0)$ & $0(0)$ & 1.000
\end{tabular}

Values are expressed as number (\%) or mean \pm standard deviation. Abbreviations: PLD, parenchymal lung disease; C-sec, cesarean section; $\mathrm{PROM}$, premature rupture of membranes, $\mathrm{PIH}$, pregnancy induced hypertension. 
약물력 및 병리학적 융모양막염 여부에 두 군간 통계적으로 유의한 차이는 없었다(Table 1).

\section{2. 임상적 특성}

출생 1 분 아프가 점수에서는 PLD group에서 7.2 1 .9점으로 idiopathic group 8.1 \pm 1.0 점 보다 낮았으나 $(P=0.038)$, 출생 5 분 아프가 점수는 두 군간 유의한 차이는 없었다 $(P=0.291)$. 태변착색 여부는 PLD group에서 21명(58.3\%), idiopathic group에서 3명(14.3\%)로 PLD group에서 유의하게 많았으며 $(P=0.041)$, 분만장에서 양압환기 시행 여부에서도 PLD group에서 10명(27.8\%), idiopathic group에 서 1명(4.8\%)으로 PLD group에서 유의하게 많았으며 $(P=0.041)$, 분

Table 2. Clinical Characteristics of the Persistent Pulmonary Hypertension of Newborn with Parenchymal Lung Diseases and Idiopathic PPHN

\begin{tabular}{|c|c|c|c|}
\hline & $\begin{array}{l}\text { PLD group } \\
\quad(n=36)\end{array}$ & $\begin{array}{l}\text { Idiopathic group } \\
\qquad(\mathrm{n}=21)\end{array}$ & $\begin{array}{c}P \text { - } \\
\text { value }\end{array}$ \\
\hline GA (wks) & $38^{+4} \pm 2^{+0}$ & $38^{+6} \pm 1^{+5}$ & 0.568 \\
\hline Birth weight (g) & $3,033 \pm 528$ & $3,211 \pm 617$ & 0.254 \\
\hline Male & $19(52.8)$ & $10(47.6)$ & 0.707 \\
\hline Inborn & $8(22.2)$ & $4(19.0)$ & 1.000 \\
\hline \multicolumn{4}{|l|}{ Apgar score } \\
\hline 1 minute & $7(5-9)$ & $8(7-9)$ & 0.038 \\
\hline 5 minute & $8.5(7-9)$ & $9(8-10)$ & 0.291 \\
\hline SGA & $3(8.3)$ & $3(14.3)$ & 0.659 \\
\hline $\begin{array}{l}\text { Meconium staining amniotic } \\
\text { fluid }\end{array}$ & 21 & $3(14.3)$ & 0.041 \\
\hline Delivery room PPV & $10(27.8)$ & $1(4.8)$ & 0.041 \\
\hline $\begin{array}{l}\text { Delivery room endotracheal } \\
\text { meconium aspiration }\end{array}$ & $11(30.6)$ & $1(4.8)$ & 0.040 \\
\hline SS stage & $1.53 \pm 0.60$ & $1.48 \pm 0.60$ & 0.758 \\
\hline Seizure & $3(8.3)$ & $3(14.3)$ & 0.659 \\
\hline $\mathrm{IVH}$ & $2(5.6)$ & $1(4.8)$ & 1.000 \\
\hline Pneumothorax & $4(11.1)$ & $2(9.5)$ & 1.000 \\
\hline Pulmonary hemorrhage & $4(11.1)$ & $1(4.8)$ & 0.642 \\
\hline Neonatal sepsis & $5(13.9)$ & $3(14.3)$ & 1.000 \\
\hline Hypoglycemia & $5(13.9)$ & $1(4.8)$ & 0.397 \\
\hline Hyperglycemia & $4(11.1)$ & $6(28.6)$ & 0.148 \\
\hline Hypocalcemia & $11(30.6)$ & $5(23.8)$ & 0.585 \\
\hline $\mathrm{ARF}$ & $12(33.3)$ & $4(19.0)$ & 0.362 \\
\hline Death & $1(2.8)$ & $4(19.0)$ & 0.056 \\
\hline
\end{tabular}

Values are expressed as number (\%) or mean \pm standard deviation or median and ranges.

Abbreviations: PLD, parenchymal lung disease; GA, gestational age; SGA, small for gestational age; PPV, positive pressure ventilation; SS stage, Sarnat and Sarnat stage; IVH, intraventricular hemorrhage; ARF, acute renal failure.
만장에서 기관내 태변 흡인 여부도 PLD group에서 11명(30.6\%)으로 idiopathic group 1명(4.8\%)에 비해 유의하게 더 많았다 $(P=0.040)$. 사망의 경우에는 PLD group에서 1명(2.8\%), idiopathic group 4명 (19.0\%)으로 idiopathic group에서 더 높은 발생을 보였으나 통계적 으로는 유의하지 않았다 $(P=0.056)$.

재태연령, 출생 체중, 성별, 출생 위치, 부당중량아 여부, 부당경량 아 여부, 분만 직후 태변착색 여부, 저산소성 허혈성 뇌증, 경련, 기 흉, 뇌실 내 출혈, 폐출혈, 신생아 패혈증, 저혈당, 고혈당, 저칼슘혈 증 및 급성 신부전 여부 등은 두 군간 유의한 차이를 보이지 않았다 (Table 2).

\section{3. 혈액 검사 및 심장 초음파 검사}

출생 이후 처음 시행한 모세관가스분석결과에서 $\mathrm{pH}$ 는 PLD

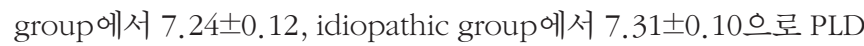
group에서 유의하게 낮게 나왔으나 $(P=0.035)$, 그 이외에 일반 혈액 검사, 생화학 검사 및 $\mathrm{pH}$ 이외의 모세관가스분석결과는 두 군간 유 의한 차이를 보이지는 않았다(Table 3 ).

\section{4. 치료}

두 군간에 인공 폐 표면 활성제 사용 여부에서는 PLD group에서

Table 3. Laboratory Findings of the Patients with Persistent Pulmonary Hypertension of the Newborn with Parenchymal Lung Diseases and Idiopathic PPHN

\begin{tabular}{|c|c|c|c|}
\hline & $\begin{array}{l}\text { PLD group } \\
\quad(n=36)\end{array}$ & $\begin{array}{l}\text { Idiopathic group } \\
\qquad(n=21)\end{array}$ & $\begin{array}{c}P \text { - } \\
\text { value }\end{array}$ \\
\hline 1st hemoglobin & $16.00 \pm 2.99$ & $16.38 \pm 2.57$ & 0.631 \\
\hline 1st WBC & $20,105 \pm 9,214$ & $20,140 \pm 6,392$ & 0.988 \\
\hline 1st PLT & $238,777 \pm 66,944$ & $261,000 \pm 76,188$ & 0.256 \\
\hline 1st CRP & $0.68 \pm 1.02$ & $1.04 \pm 1.65$ & 0.373 \\
\hline 1st CBGA(pH) & $7.24 \pm 0.12$ & $7.31 \pm 0.10$ & 0.035 \\
\hline 1st CBGA(pCO2) & $55.90 \pm 22.57$ & $47.79 \pm 17.09$ & 0.160 \\
\hline 1st CBGA(pO2) & $41.33 \pm 18.08$ & $37.79 \pm 15.42$ & 0.457 \\
\hline 1st CBGA(BE) & $-4.31 \pm 4.69$ & $-3.08 \pm 3.78$ & 0.308 \\
\hline $\begin{array}{l}\text { Lowest CBGA pH within } \\
\text { first } 72 \text { hours }\end{array}$ & $7.21 \pm 0.12$ & $7.23 \pm 0.16$ & 0.470 \\
\hline $\begin{array}{l}\text { Lowest CBGA pCO }{ }_{2} \\
\text { within first } 72 \text { hours }\end{array}$ & $31.51 \pm 5.60$ & $31.65 \pm 10.27$ & 0.955 \\
\hline $\begin{array}{l}\text { Lowest CBGA BE within } \\
\text { first } 72 \text { hours }\end{array}$ & $-6.29 \pm 5.42$ & $-6.27 \pm 3.35$ & 0.987 \\
\hline $\begin{array}{l}\text { Highest CBGA } \mathrm{PCO}_{2} \\
\text { within first } 72 \text { hours }\end{array}$ & $59.86 \pm 17.53$ & $58.40 \pm 23.74$ & 0.792 \\
\hline
\end{tabular}

Value are expressed as number (\%) or mean \pm standard deviation. Abbreviations: PLD, parenchymal lung disease; WBC, white blood cell; PLT, platelet; CRP, C-reactive protein; CBGA, capillary blood gas analysis; $\mathrm{BE}$, base excess. 
Table 4. Treatment of the Patients with Persistent Pulmonary Hypertension of the Newborn with Parenchymal Lung Diseases and Idiopathic PPHN

\begin{tabular}{|c|c|c|c|}
\hline & $\begin{array}{l}\text { PLD group } \\
(\mathrm{n}=36)\end{array}$ & $\begin{array}{l}\text { Idiopathic group } \\
\qquad(n=21)\end{array}$ & $\begin{array}{c}P- \\
\text { value }\end{array}$ \\
\hline Hospital stay (d) & $24.0 \pm 11.6$ & $22.4 \pm 13.8$ & 0.653 \\
\hline Surfactant uses & $22(61.1)$ & $7(33.3)$ & 0.043 \\
\hline Oxygen treatment period (d) & $13.2 \pm 9.3$ & $13.8 \pm 12.5$ & 0.836 \\
\hline $\begin{array}{l}\text { Invasive MV maintenance } \\
\text { period (d) }\end{array}$ & $8.14 \pm 7.18$ & $9.76 \pm 11.34$ & 0.511 \\
\hline HFOV uses & $13(36.1)$ & $9(42.9)$ & 0.614 \\
\hline iNO uses & $23(63.9)$ & $14(66.7)$ & 0.832 \\
\hline Sidenafil uses & $20(55.6)$ & $13(61.9)$ & 0.640 \\
\hline Iloprost uses & $18(50.0)$ & $10(47.6)$ & 0.862 \\
\hline Bosentan uses & $7(19.4)$ & $9(42.9)$ & 0.050 \\
\hline Milrinone uses & $3(8.3)$ & $1(4.8)$ & 1.000 \\
\hline Dopamine uses & $18(50.0)$ & $13(61.9)$ & 0.384 \\
\hline Epinephrine uses & $8(22.2)$ & $11(52.4)$ & 0.020 \\
\hline Vasopressin uses & $2(5.6)$ & $0(0)$ & 0.526 \\
\hline Hydrocortisone uses & $7(19.4)$ & $6(28.6)$ & 0.428 \\
\hline Sedative uses & $32(88.9)$ & $18(85.7)$ & 0.701 \\
\hline Duration of sedative uses (d) & $6.61 \pm 5.82$ & $9.62 \pm 12.34$ & 0.217 \\
\hline Duration of inotropics uses (d) & $3.67 \pm 4.79$ & $5.95 \pm 12.15$ & 0.319 \\
\hline Antibiotic uses & $36(100)$ & $19(90.5)$ & 0.132 \\
\hline IVIG uses & $10(27.8)$ & $7(33.3)$ & 0.658 \\
\hline pRBC transfusion & $9(25.0)$ & $4(19.0)$ & 0.748 \\
\hline FFP transfusion & $7(19.4)$ & $6(28.6)$ & 0.428 \\
\hline Platelet transfusion & $2(5.6)$ & $1(4.8)$ & 1.000 \\
\hline
\end{tabular}

Values are expressed as number (\%) or mean \pm standard deviation. Abbreviations: PLD, parenchymal lung disease; MV, mechanical ventilator; HFOV, high frequency oscillatory ventilator; iNO, inhaled nitric oxide; IVIG, intravenous immunoglobulin; pRBC, packed red blood cell; FFP, fresh frozen plasma.

22명(61.1\%), idiopathic group에서 7명(33.3\%)으로 PLD group에 서 더 많았다 $(P=0.043)$. Bosentan 사용 여부는 PLD group에서 7명 (19.4\%), idiopathic group에서 9명(42.9\%)으로 idiopathic group에 서 더 많이 사용경향을 보였으나 통계적으로 유의하지는 않았다 $(P=$ 0.050). Epinephrine 사용의 경우에는 PLD group에서 8명(22.2\%), idiopathic group에서 11명(52.4\%)으로 idiopathic group에서 더 많 이 사용하였다 $(P=0.020)$. 그 이외에 입원 기간, 산소 투여 기간, 인공 환기기 적용 기간, 고빈도 환기기 사용 유무, 흡입 일산화 질소 사용 유무, sildenafil, iloprost, milrinone 사용 여부, dopamine, vasopres $\sin$, hydrocortisone 사용 여부, 진정제 사용여부(fentanyl 또는 midazolam), 항생제 사용 여부 및 면역 글로불린 투여 여부, 적혈구, 신선 동결 혈장, 혈소판 수혈 여부에서 두 군간에 큰 차이는 없었다 (Table 4).

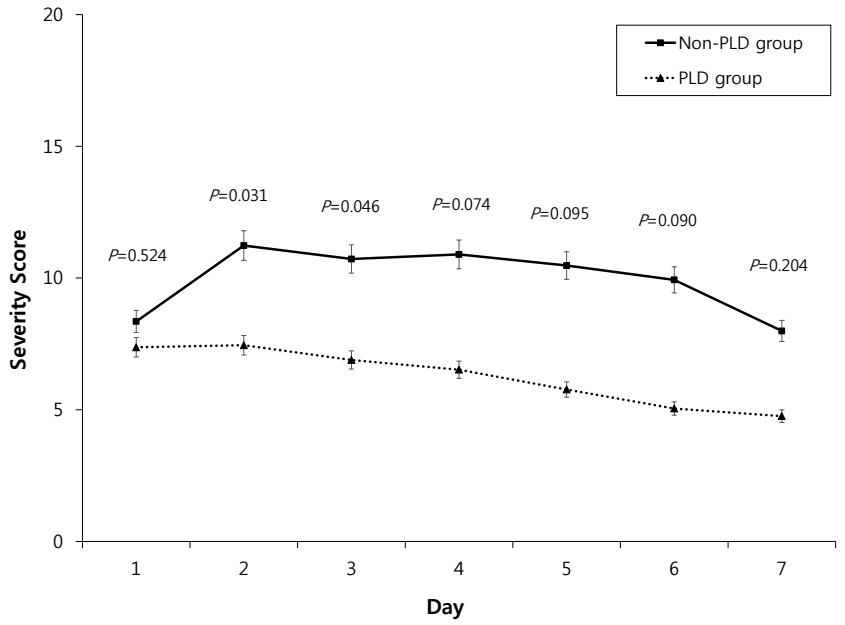

Figure 2. Comparisons of severity scores between two groups. Severity score $\left(\mathrm{FiO}_{2} \times \mathrm{MAP}\right)$ in overall first week after birth were higher in idiopathic group than PLD group. Abbreviations: PLD, parenchymal lung disease; $\mathrm{FiO}_{2}$, fraction of inspired oxygen; MAP, mean airway pressure.

입 원 이후 7일간의 SS에서는 1 일째부터 7일째까지 모두 idiopathic group에서 PLD group보다 높은 추세를 보였고, 생후 4-7일째 에서는 와 3일째만 통계적으로 유의하게 idiopathic group에서 더 높 은 점수를 보였다(Figure 2).

\section{고찰}

기존 신생아 폐동맥고혈압증에 대한 원인 및 위험요인에 대한 국 내외 연구들은 많았으나, 본 연구는 PLD group과 idiopathic group 으로 나눠 두군 간의 비교를 증상으로 대변할 수 있는 SS로 시행한 국내 최초의 논문이다.

기존에 SS를 이용한 논문들을 살펴보면 Mhanna 등 ${ }^{22)}$ 의 연구에 따 르면 SS 점수가 높은 경우에 기관 발관 실패 확률이 높아진다는 연 구가 있었으며, 국내 논문에서도 48시간 이상의 기계환기요법을 필 요로 했던 중증 MAS 12명을 대상으로 하였으며, 이중 8명이 PPHN 으로 진단 받았으며 PPHN군이 대조군에 비해 폐표면활성제 치료 를 받기 전과 2일째까지 통계적으로 유의하게 SS가 높았다. 그러나 $\mathrm{PPHN}$ 에서 RDS에 합당한 소견을 보이지 않은 경우 인공 폐 표면 활 성제 치료가 SS에 영향을 주지 못하였다 ${ }^{24)}$.

PPHN 원인에 따른 예후에 대한 기존 연구들을 살펴보면, Steurer 등 $^{25}$ 의 연구에서는 34 주 이상의 3,277 명의 PPHN 환자를 대상으로 조사하였는데, PLD group인 MAS 799명(24.4\%), RDS 231명(7.1\%), infection associated RDS 982 (30.0\%)명이였으며 이외에 idiopathic 646명(19.7\%), 선천성 횡격막 탈장 200명(6.1\%), 선천성 기형 155명 (4.7\%), 다른 원인 264명(8.1\%)이었다. 이중 PLD group과 idiopathic 
group만을 놓고 보았을 때 2,012명(75.7\%), 646명(24.3\%)이였으며, 본 연구에서는 총 57명의 PPHN 환자 중 PLD group이 36명(63.1\%), idiopathic group이 21명(36.9\%)으로 본 연구에서 idiopathic group 이 약간 많았다. Steurer 등 ${ }^{25}$ 에서는 RDS, MAS, idiopathic에 비해 선 천성횡격막 탈장, 선천성 기형 환자군의 1 년 생존율이 유의하게 낮 았다. 이에 반해 본 연구에서는 사망자수는 PLD group에서 1명 (2.8 $\%$ ), idiopathic group 4명(19.0\%)으로 idiopathic group 에서 더 높은 사망률을 보였으나 통계적으로 유의하지 않았다 $(P=0.056)$. 본 연구 는 입원 기간 동안의 단기적인 예후만 살펴보았으나 Martin의 연구 와 비슷하게 두 군간의 유의한 사망률의 차이는 보이지 않았다. 다 만 idiopathic group 에서 조금 더 많은 사망 포함된 것은 이 중 흡입 일산화 질소 등 PPHN 치료에 반응을 보이지 않았던 경우가 더 많았 기 때문으로 생각된다 ${ }^{26}$.

출생 후 아프가 점수 대한 기존 연구를 살펴보면 Nakwan과 Pithaklimnuwong ${ }^{27)}$ 의 연구에서는 출생 후 1 분 및 5 분 아프가 점수는 각 8점(5-9) 및 9점(7-9)이었으며, 생존한 환자에서는 8점(5-9)및 9 점(7-9), 사망한 환자에서는 7점(6-9) 및 8점(7-9)으로 사망 환자 에서 낮게 나왔으나 통계적으로 유의하지 않았다. 본 연구에서는 1 분 및 5분 아프가 점수가 각 PLD group에서 7점(5-9) 및 8.5점(710), idiopathic group에서 8점(7-9) 및 9점(8-10)으로 PLD group 에서 더 낮았으며, 그 중 1 분 아프가 점수의 경우에는 통계적으로 유 의한 결과를 얻을 수 있었다 $(P=0.038)$. 이러한 차이를 보인 이유에 는 분만 당시 심한 태변 착색 등으로 인해, 출생 직후에는 1 분 아프 가 점수가 PLD group에서 더 낮았을 것으로 생각되며, 분만장에서 의 기관 내 태변 흡입이나, 양압환기 등의 소생술 후에 회복되어 5 분 아프가에서는 두 군간의 차이가 감소한 것으로 생각된다. 실제 로도 본 연구에서 분만장에서의 양압환기의 경우는 PLD group에 서 10명(27.8\%)으로 idiopathic group에서 1명(4.8\%) 보다 많았으며 $(P=0.041)$, 기관 내 태변 흡인 여부는 PLD group에서 11명 $(30.6 \%)$, idiopathic group에서 1명 $(4.8 \%)$ 으로 많았다 $(P=0.040)$. 태변 흡입 증후군 환자에서 폐혈관 수축을 조장할 수 있는 저체온증, 산혈증, 저산소증 및 허혈 등이 흔히 나타날 수 있는 것으로 알려져 있는 데 ${ }^{28)}$, 본 연구에서도 도착 후 첫 모세혈액가스검사 $\mathrm{pH}$ 가 PLD group에 서 idiopathic group보다 더 낮은 것을 확인 할 수 있었다. PPHN 발 생 시점은 Zubrow 등 ${ }^{29)}$ 에서 19명 중 16 명이 2일 이내에 발병하였으 며, 본 연구에서도 PLD group에서 1.69 \pm 0.66일 idiopathic group에 서 $1.67 \pm 0.65$ 일로 두 군간의 차이는 없었으나 2 일 이내에 발병하여 기존연구와 비슷한 결과를 보였다 $(P=0.880)$.

치료 측면에서 우선 인공 폐 표면 활성제 사용에 대한 기존 연구를 살펴보면 Lotze 등 ${ }^{30}$ 에서 심한 호흡부전을 가진 만삭아에서 인공 폐 표면 활성제 사용 시 OI를 낮추고 $(P=0.013)$, 체외막 산소공급(extracorporeal membrane oxygenation, ECMO) 사용률을 낮추는 것으로 알려졌으나 $(P=0.038)$, 특발성 $\mathrm{PPHN}$ 군에서는 유의한 결과를 얻지 못
하였다. 본 연구에서도 PLD group 22명(61.1\%), idiopathic group에 서 7명(33.3\%)에서 surfactant를 투여하였으며 통계적으로 유의한 차 이를 보였는데 $(P=0.043)$, 이는 본 연구의 환자군 분류에서 기인한 것 으로 보인다. 그리고, bosentan 사용에 대한 기존연구를 보면 Choudhary 등 ${ }^{31}$ 에서 meconium aspiration syndrome에서 bosentan 사용 군 14명(53.8\%), 비투여군 12명(46.2\%)이었으며, hyaline membrane disease에서 bosentan 사용 군 3명(42.8\%), 비투여군 4명(57.2\%)이 었고, idiopathic 군에서는 bosentan 3명(60\%), 비투여군 2명(40\%) 으로 bosentan 사용여부에 큰 차이가 없었으며, 본 연구에서는 PLD group에서는 7명(19.4\%), idiopathic group에서는 9명(42.9\%)으로 idiopathic group에 더 많이 쓰는 경향을 보였으나 통계적으로 유의 하지 않았는데 $(P=0.050)$, 이는 idiopathic group에서 PLD group 보 다 심한 경과를 보여, 보조적 치료로 더 사용하였을 것으로 보인다. 마찬가지 이유로 적절한 혈압 유지를 위해 사용한 epinephrine 역시 각각 PLD group에서 8명(22.2\%), idiopathic group에서 11명(52.4\%) 으로 idiopathic group에서 많이 사용된 것 역시 더 심한 경과를 보이 는 환자가 idiopathic group에 많은 것으로 설명할 수 있을 것이다 $(P=$ 0.020).

PPHN의 중증도를 비교하기 위해 조사한 SS는 생후 1-7일간 PLD group보다 idiopathic group에서 지속적으로 높은 경향을 보였다. 그 중에서도 생후 4-7일째 비교한 SS에서는 idiopathic group에서 통계적으로 유의한 정도로 PLD group에 비하여 더 높았다 $(P<0.05)$. 이러한 이유로는 출생 직후 심한 폐실질 질환으로 idiopathic group 과 큰 차이가 나지 않았던 중증도 점수가 치료 기간이 길어짐에 따라 PLD group은 어느 정도 치료에 반응 정도가 빠른 반면에 idiopathic group은 상대적으로 치료에 반응이 적거나 느려서 생후 4 일째 이후 에 차이가 나는 것으로 보여진다.

이번 연구에서 제한점으로는 신생아 지속성 신생아 폐동맥 고혈 압 질병 증증도를 비교하기 위해 $\mathrm{OI}=\mathrm{FiO}_{2} \times \mathrm{MAP} / \mathrm{PaO}_{2}$ 라는 지표를 많 이 사용하고 있으나 ${ }^{29)}$, 본 연구에서는 모든 환자의 동맥혈 가스분석 결과를 확인하지 못하여 $\mathrm{FiO}_{2} \times \mathrm{MAP} / \mathrm{PaO}_{2}$ 에서 $\mathrm{PaO}_{2}$ 를 제외한 수치 인 SS로 비교한 점이 아쉬운 점이다. 또한 대규모의 전향적인 연구가 아닌 단일 기관의 후향적 차트연구라는 점도 이 연구의 한계점이다.

본 연구는 PLD group 환자가 idiopathic group 환자에 비하여 비 교적 SS가 비교적 낮아 증상이 좀더 경했다고 할 수 있으나, 사망이 나 입원기간, 기계환기기 적용기간 등의 예후에서는 두군 간에 큰 차 이를 보이지 않았다. 따라서 더 정확한 분석을 위해서는 단, 장기적 예후를 포함한 5-10년 이상의 전향적인 다기관 연구가 필요하리라 생각된다. 


\section{REFERENCES}

1) Levin DL, Heymann MA, Kitterman JA, Gregory GA, Phibbs $\mathrm{RH}$, Rudolph AM. Persistent pulmonary hypertension of the newborn infant. J Pediatr 1976;89:626-30.

2) Son SB, Kim KA, Yun SY, Ko SY, Lee YK, Shin SM. Oral sildenafil in persistent pulmonary hypertension of the newborn. J Korean Soc Neonatol 2011;18:124-9.

3) Walsh MC, Stork EK. Persistent pulmonary hypertension of the newborn. Rational therapy based on pathophysiology. Clin Perinatol 2001;28:609-27.

4) Rudolph AM. High pulmonary vascular resistance after birth: I. Pathophysiologic considerations and etiologic classification. Clin Pediatr (Phila) 1980;19:585-90.

5) Geggel RL, Reid LM. The structural basis of PPHN. Clin Perinatol 1984;11:525-49.

6) Bendapudi P, Rao GG, Greenough A. Diagnosis and management of persistent pulmonary hypertension of the newborn. Paediatr Respir Rev 2015;16:157-61.

7) Jain A, McNamara PJ. Persistent pulmonary hypertension of the newborn: Advances in diagnosis and treatment. Semin Fetal Neonatal Med 2015;20:262-71.

8) Sweet DG, Carnielli V, Greisen G, Hallman M, Ozek E, Plavka R, et al. European consensus guidelines on the management of respiratory distress syndrome - 2016 update. Neonatology 2017; 111:107-25.

9) Dargaville PA, Copnell B. The epidermiology of meconium aspiration syndrome: incidence, risk factors, therapies, and outcome. Pediatrics 2006;117:1712-21.

10) Keszler M, Carbone MT, Cox C, Schumacher RE. Severe respiratory failure after elective repeat cesarean delivery: a potentially preventable condition leading to extracorporeal membrane oxygenation. Pediatrics 1992;89:670-2.

11) Phelan JP, Smith CV, Broussard P, Small M. Amniotic fluid volume assessment with the four-quadrant technique at 36-42 weeks' gestation. J Reprod Med 1987;32:540-2.

12) Visintin C, Mugglestone MA, Almerie MQ, Nherera LM, James D, Walkinshaw S. Management of hypertensive disorders during pregnancy: summary of NICE guidance. BMJ 2010; 341:c2207.

13) Practice bulletin No. 180 summary: gestational diabetes mellitus. Obstet Gynecol 2017;130:244-6.

14) Practice bulletin No. 139: premature rupture of membranes. Obstet Gynecol 2013;122:918-30.

15) Sarnat HB, Sarnat MS. Neonatal encephalopathy following fetal distress. A clinical and electroencephalographic study. Arch Neurol 1976;33:696-705.

16) Volpe JJ. Intraventricular hemorrhage and brain injury in the premature infant. Diagnosis, prognosis, and prevention. Clin Perinatol 1989;16:387-411.
17) Bone RC, Balk RA, Cerra FB, Dellinger RP, Fein AM, Knaus WA, et al. Definitions for sepsis and organ failure and guidelines for the use of innovative therapies in sepsis. Chest 1992;101:164455.

18) Adamkin DH. Postnatal glucose homeostasis in late-preterm and term infants. Pediatrics 2011;127:575-9.

19) Ogilvy-Stuart AL, Beardsall K. Management of hyperglycaemia in the preterm infant. Arch Dis Child Fetal Neonatal Ed 2010;95: F126-31.

20) Jain A, Agarwal R, Sankar MJ, Deorari A, Paul VK. Hypocalcemia in the newborn. Indian J Pediatr 2010;77:1123-8.

21) Barletta GM, Bunchman TE. Acute renal failure in children and infants. Curr Opin Crit Care 2004;10:499-504.

22) Mhanna MJ, Iyer NP, Piraino S, Jain M. Respiratory severity score and extubation readiness in very low birth weight infants. Pediatr Neonatol 2017. doi: 10.1016/j.pedneo.2016.12.006.

23) Ballard RA, Truog WE, Cnaan A, Martin RJ, Ballard PL, Merrill JD, et al. Inhaled nitric oxide in preterm infants undergoing mechanical ventilation. N Engl J Med 2006;355:343-53.

24) Choi CW, Kim BI, Lee HJ, Joung KE, Shim GH, Lim IS, et al. Clinical characteristics of severe meconium aspiration syndrome. Korean J Pediatr 2008;51:713-21.

25) Steurer MA, Jelliffe-Pawlowski LL, Baer RJ, Partridge JC, Rogers EE, Keller RL. Persistent pulmonary hypertension of the newborn in late preterm and term infants in California. Pediatrics 2017;139. doi: 10.1542/peds.2016-1165. Epub 2016 Dec 1.

26) Kim SD, Song YH, Shim GH, Kim DH, Lee JA, Shin YJ,et al. Predictors of clinical outcome in the newborn of persistant pulmonary hypertension treated with inhaled nitric oxide. J Korean Soc Neonatol 2002;9:133-40

27) Nakwan N, Pithaklimnuwong S. Acute kidney injury and pneumothorax are risk factors for mortality in persistent pul. monary hypertension of the newborn in Thai neonates. J Matern Fetal Neonatal Med 2016;29:1741-6.

28) Edwards MO, Kotecha SJ, Kotecha S. Respiratory distress of the term newborn infant. Paediatr Respir Rev 2013;14:29-3, quiz -7.

29) Zubrow AB, Hulman $S$, Kushner H, Falkner B. Determinants of blood pressure in infants admitted to neonatal intensive care units: a prospective multicenter study. Philadelphia Neonatal Blood Pressure Study Group. J Perinatol 1995;15:470-9.

30) Lotze A, Mitchell BR, Bulas DI, Zola EM, Shalwitz RA, Gunkel $\mathrm{JH}$. Multicenter study of surfactant (beractant) use in the treatment of term infants with severe respiratory failure. Survanta in Term Infants Study Group. J Pediatr 1998;132:40-7.

31) Choudhary M, Meena MK, Chhangani N, Sharma D, Choud hary JS, Choudhary SK. To study prevalence of persistent pulmonary hypertension in newborn with meconium aspiration syndrome in western Rajasthan, India: a prospective observational study. J Matern Fetal Neonatal Med 2016;29:324-7. 